$+$

\author{
Vijay SHENAI, \\ Artem SHCHERBYNA, \\ Sergei VORONIN, \\ Dmitriy OLKHOVSKYY
}

\title{
THE DETERMINANTS OF FDI IN SIX FORMER FSU COUNTRIES: A STUDY OF DATA 1995-2017
}

\begin{abstract}
Foreign Direct Investment (FDI) can bring in much needed capital, particularly in emerging markets, help improve manufacturing and trade sectors, bring in more efficient technologies, increase local production and exports, create jobs and develop local skills, bring about improvements in soft and hard infrastructure and overall be a contributor to sustainable economic growth in the Gross Domestic Product (GDP). With all these desirable features, it becomes relevant to ascertain the factors which attract FDI to an economy or a group of adjacent economies. This paper explores the determinants of FDI in six Former Soviet Union (FSU): Ukraine, Belarus, Armenia, Russia, Moldova and Kazakhstan. After an extensive literature review of theories and empirical research and using a set of cross-sectional data over the period 1995-2017, an ARDL model is estimated
\end{abstract}

(C) Vijay Shenai, Artem Shcherbyna, Sergei Voronin, Dmitriy Olkhovskyy, 2020.

Shenai Vijay, PhD (Economics), Professor at University of Lincoln, UK. Email: kvshenai11@gmail.com. Shcherbyna Artem, PhD (Economics), Associate Professor at Department of Finance, Kyiv National Economic University, Ukraine.

Voronin Sergei, MBA, Volgograd State Technical University, Russia.

Olkhovskyy Dmitriy, MPA, Kharkiv National University of Economics, Ukraine. 
with FDI/GDP as the dependent variable. Inflation, exchange rate changes, openness, economy size (GDP), Income levels (GNI per capita), Infrastructure (measured by the number of fixed line and mobile subscription per 100 persons) are tested as independent variables for explanatory power in long run and short run relationships. Over the period, higher inflows of FDI in relation to GDP appear to be have been attracted to the markets with better infrastructure, smaller markets and higher income levels, with lower openness, depreciation in the exchange rate and higher income levels though the coefficients of the last three variables are not significant. The results show the type of FDI attracted to investments in this region and are evaluated from theoretical and practical view points. Policy recommendations are made to enhance FDI inflows and further economic development in this region. Such a study of this region has not been made in the past.

\section{Key words:}

Determinants of FDI; FDI flows; cross-sectional analysis; FSU.

JEL: C21, F21, F23.

\subsection{Introduction}

\subsection{Background}

Countries which are restructuring their economies need capital. Capital can come into an economy across national borders, in many forms. as it seeks the highest rate of return for that class of investment. Foreign direct investment $(F D I)$ is defined as an investment involving a long-term relationship and reflecting a lasting interest and control by a resident entity in one economy (foreign direct investor or parent enterprise) in an enterprise resident in an economy other than that of the foreign direct investor (FDI enterprise or affiliate enterprise or foreign affiliate (IMF(1993), OECD(1996)). FDI implies that the investor exerts a significant degree of influence on the management of the enterprise resident in 
the other economy. Such investment is usually by way of equity capital, implying long term involvement and is preferred over other private capital flows such as portfolio investments which are considered short-term. and can flow out much more easily. The resilience of foreign direct investment during financial crises lead many developing countries to regard it as the private capital inflow of choice (Loungani and Razin (2001)). Moreover, FDI brings in efficient technologies and capital inputs, human capital development via training of local employees, and contributes to corporate tax revenues in the host country (Feldstein (2000)). Higher production and exports are and other improvements in soft and hard infrastructure suggest it can be overall contributor to sustainable economic growth. By contrast, Portfolio Investment Flows (PFI) are capital flows into a country which seek financial returns in the short and medium terms through investment in the stock and bond markets. PFI is generally not preferred by countries because it is linked with rapid outflows in crisis times, destabilizing the operations of local financial markets.

\subsection{Trends in World FDI inflows}

The inflow of FDI into various regions and economies are presented in Figure 1. FDI inflows in 2005 were about US $\$ 1$ trillion in 2005 , rising to US $\$ 1.92$ trillion in 2015 but falling to US $\$ 1.43$ trillion in 2017 . The fluctuations in FDI inflows are ascribed to factors such as corporate takeover waves and instability in commodity prices (World Investment Report 2018).

In 2017, the Developed economies in Europe and North America received $50 \%$ ( $\$ 712$ million) of total FDI inflows, and Transition economies received $\$ 47$ billion of FDI inflows, representing 3.2\% of the FDI inflows. Transition economies are economies in South East Europe (Albania, Montenegro, Serbia, Bosnia Herzogovina, Macedonia) and the 12 Former Soviet Union Countries. The geographical distribution of inflows remained highly concentrated: of the transition economies, the top 5 (the Russian Federation (US\$25.3bn), Kazakhstan (US\$4.6bn), Azerbaijan (US\$2.9bn), Serbia (US\$2.9bn) and Turkmenistan (US\$2.3bn)), received 81 per cent of all FDI to the group. FDI flows to Ukraine in 2017 were just $\$ 2.2$ billion, in the face of policy and political uncertainty.

The countries with the largest investments by FDI stock in Transition Economies, in 2016, were Cyprus (US\$31bn), France US\$28bn, Germany US\$24(bn), China US\$23bn and Italy (US\$20bn) (UNCTAD, World Investment Report (2018)). Given the structure and resources of the economies in the previously Centrally Planned Economy era, all types of FDI come into transition economies: market seeking, resource seeking and efficiency seeking. 
Figure 1

World FDI inflows: 2005-2017

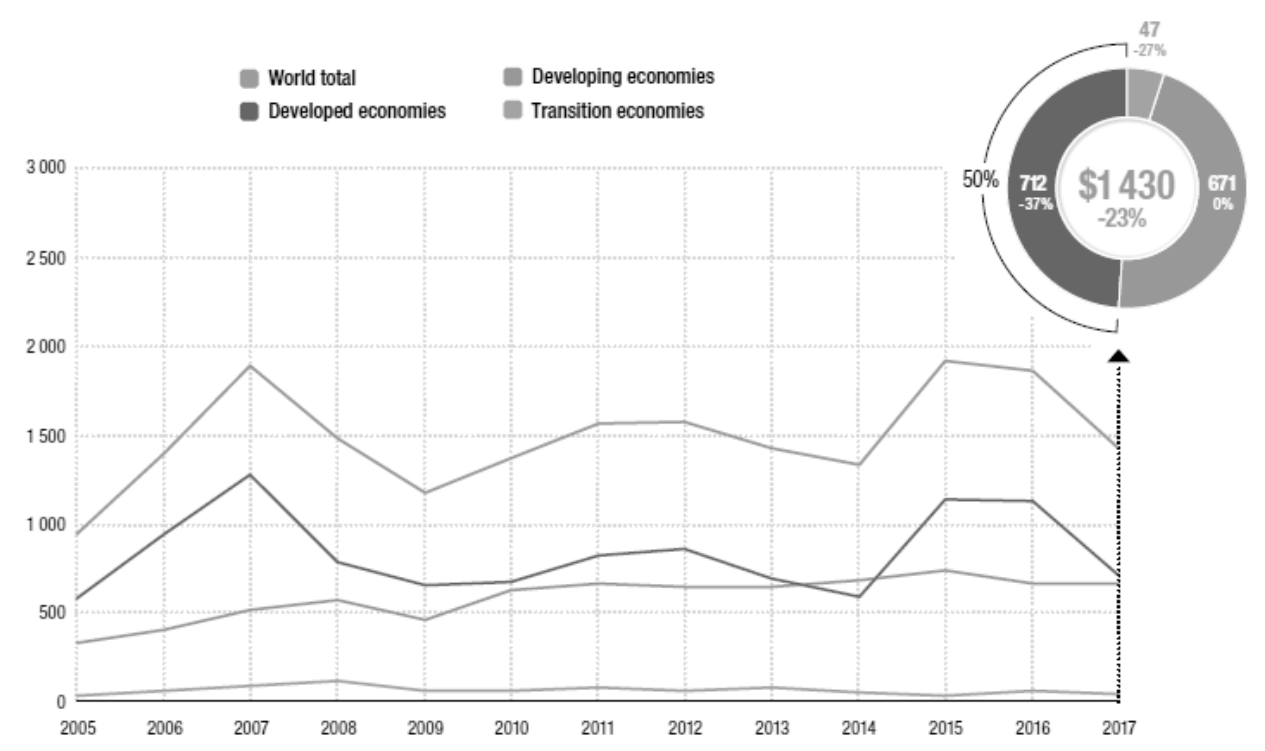

$y$-axis: in current trillion US\$

Source: UNCTAD (FDI/MNE database: www.unctad.org/fdistatistics)

Figure 2

FDI inflows 2015-17 to regions and economies (USD \$billion)

\begin{tabular}{lrrr} 
& & & \\
Group of economies/region & $\mathbf{2 0 1 5}$ & $\mathbf{2 0 1 6}$ & $\mathbf{2 0 1 7}$ \\
\hline World & $\mathbf{1 9 2 1}$ & $\mathbf{1 8 6 8}$ & $\mathbf{1 4 3 0}$ \\
Developed economies & $\mathbf{1 1 4 1}$ & $\mathbf{1 1 3 3}$ & $\mathbf{7 1 2}$ \\
$\quad$ Europe & 595 & 565 & 334 \\
North America & 511 & 494 & 300 \\
Developing economiles & $\mathbf{7 4 4}$ & $\mathbf{6 7 0}$ & $\mathbf{6 7 1}$ \\
$\quad$ Africa & 57 & 53 & 42 \\
Asia & 516 & 475 & 476 \\
Latin America and the Caribbean & 169 & 140 & 151 \\
Transition economies & $\mathbf{3 6}$ & $\mathbf{6 4}$ & $\mathbf{4 7}$ \\
\hline
\end{tabular}

Source: UNCTAD (FDI/MNE database: www.unctad.org/fdistatistics) 


\subsection{Six largest states from the FSU}

Russia, Belarus, Kazakhstan, Moldova and Armenia are the six largest states in the FSU. FSU countries chose to split from the USSR, a Centrally Planned System and move to independence in December 1991. Since then, FSU countries have been following economic transformation to market economies to varying degrees. Some relevant demographic characteristics of these countries are summarized in the Table 1 below.

Table 1

Some relevant demographics of the FSU countries in this research

\begin{tabular}{|l|c|c|c|c|}
\hline \multicolumn{1}{|c|}{ Country } & $\begin{array}{c}\text { Population } \\
(2019)\end{array}$ & Area $\left(\mathrm{km}^{2}\right)$ & $\begin{array}{c}\text { Real GDP (mill\$) } \\
2017\end{array}$ & $\begin{array}{c}\text { GNIPC }(\$) \\
2017\end{array}$ \\
\hline Armenia & 2957731 & 29743 & 12364648565 & 8342 \\
\hline Belarus & 9452411 & 207600 & 62013997099 & 16131 \\
\hline Kazakhstan & 18551427 & 2724900 & 196029836978 & 22062 \\
\hline Moldova & 4043263 & 33846 & 7685763946 & 5328 \\
\hline Russia & 145872256 & 17098242 & 1680006793868 & 23843 \\
\hline Ukraine & 43999022 & 603628 & 127296360704 & 7593 \\
\hline
\end{tabular}

The inflows of FDI to the six countries of this study: Ukraine, Belarus, Armenia, Russia, Moldova and Kazakhstan are no exception to the research and theoretical findings of scholars. Most of the selected countries are emerging markets with a market-based economy and improvements are necessary in infrastructure, particularly soft infrastructure (market based institutional infrastructure needs development), exports need development, internal manufacturing facilities need modernization and expansion. Therefore, these countries heavily rely on the inflow of foreign direct investment as well as foreign aid from global community to drive the transformation process. The World Bank, International Monetary Fund and other institutions have consistently assessed and supported the growth of the countries' economy through budgetary support and capacity building in key public institutions of government. Foreign direct investment plays a major role in developing an economy with respect to domestic savings, filling employment gap, and developing skills of locals among others. 


\subsection{Aim of this paper}

The aim of the current research is to determine through research, the determinants of FDI flows in six FSU states: Ukraine, Belarus, Armenia, Russia, Moldova and Kazakhstan during the period 1990 to 2017, and make policy recommendations for the promotion of FDI and economic growth in these countries.

\subsection{Structure of this paper}

This research is divided into various sections: section 1 covered the introduction and background of the countries with respect to FDI and the investment climate and set out the aims of the current research. In section 2, theories and empirical research on FDI and its determinants are reviewed and appraised. In section 3, the methodology and econometric models used, data sources and definitions are covered. In section 4, econometric models are estimated from the data and the results are interpreted. In section, 5 the results obtained in the previous section are discussed and compared with previous research. Finally, the conclusion of the work and policy recommendations

Are presented in section 6.

\subsection{Literature Review}

The movement of capital to maximize resource utilization has made a large contribution toward stabilizing global economy over the years. Foreign direct investment is a driver of employment, technological progress, productivity improvements and economic growth. FDI enables host countries to enhance production capabilities and upgrade technology (Adam \& Tweneboah, 2009). The literature reviewed here first looks at the main theories of FDI and their implications, and then at the determinants of FDI from the perspective of the host economy.

\subsection{Main theories of FDI and their implications}

Over the years, researchers across the globe have developed four major theories on FDI: product cycle theory, perfect capital or exchange market theory, internationalization theory and the eclectic paradigm. 
According to (Vernon, 1966) product cycle theory, there are four stages of production cycle: innovation, growth, maturity and decline. In the first two stages, innovative products are created by companies for local consumption and grow in local markets. With maturity as competition grows, the surplus is exported and eventually the company make investments in foreign markets. This theory was emphasized in the work of (Foellmi, Hanslin and Kohler, 2018).

According to exchange market theory, from an exporting country's point of view, example US, an increase in RER, expressed as foreign currency/\$, decreases US export competitiveness, while a decrease in RER, expressed as foreign currency/\$ increases export competitiveness and this can explain FDI made by exporting countries. Cushman (1985) analyzed the influence of exchange rate uncertainty as a factor of FDI by American firms and showed that real exchange rate increase stimulated FDI made by USD, while a foreign currency appreciation has reduced American FDI. Although, currency risk rate theory does not explain simultaneous foreign direct investment between countries with different currencies, it is argued by proponents that such investments are made in different times.

According to Hymer (1972), to whom Internalisation theory is attributed to, MNCs make FDI to reduce competition and exploit firm specific advantages, even though relocation of activities may involve adjustment costs. Hymer (1976), further states that MNCs see opportunities through market imperfections in the final product market through capabilities not shared with competitors and a major conclusion drawn is that FDI is a firm-level strategy defusion to increase their market share in the global economy rather than a capital-market financial defusion.

According to Eclectic Paradigm theory, developed by Dunning (1977) firms make FDI investments because of three aspects: Ownership advantages, Locational advantages and Internalisation. The ownership characteristic can give a company control over resources (natural or other intangible such as patents and trademarks), technology or access to financial capital; location advantages may arise from lower operating costs, political support from host country's government or better social acceptability while finally the internalization characteristic allows a firm to set up foreign production rather than license it. The Eclectic paradigm shows that OLI parameters can vary from firm to firm and the final form it takes depends upon context and the economic, political and social characteristics of the host country.

Dunning (1993) further describes, three main types of FDI from the perspective of investing firms: Market seeking FDI, also called horizontal FDI (where the objective is to access and serve local and global markets); Resource-seeking FDI, also called vertical or export-oriented FDI, where firms invest abroad to obtain overseas resources: raw materials, labour, natural endowments (oil, gas, mineral ores). Such FDI can involve building production chains in the host coun- 
try. Effectively, vertical FDI exploits differences in factor prices. Efficiencyseeking FDI, where a firm structures its operations for economies of scale and scope through common governance of geographically dispersed activities.

While existing theories of foreign direct investment attempt to explain FDI flows in terms of multinational firms and their objectives, it is further meaningful to examine the impact of various characteristics of the economy of the host country on FDI inflows, to capture the effects of any theories, not so far postulated.

\subsection{Factors determining FDI flows from empirical research}

In the next section, empirical research on some main economic determinants of FDI inflows such as Inflation, Exchange rates, Openness, GDP (market size), Income levels (GDP per capita) and infrastructure and other enveloping issues relating to an economy are reviewed in detail.

\section{Inflation, Exchange Rates, Openness}

Froot and Stein (1991) showed that Japanese FDI into the United States followed surprisingly close movements of the yen-dollar exchange rates in the 1980s. Sayek (2009) studied cases of vertical and horizontal FDI and suggests that MNCs use FDI is used as a hedging tool for investment smoothing, mitigating the effects of inflation taxes even if there are no formal hedging mechanisms. The investment-smoothing reaction of MNEs depends on the reason for investment, the financing sources of FDI, and the substitutability between factors of production. Finally, this investments smoothing possibility (FDI) reduces the real negative effects of inflation. Valli and Masih (2014), studying data on inflation and FDI inflows into South Africa, showed that there is a degree of causality between stable inflation levels and improved FDI inflows suggesting that the policy change that occurred with the adoption of 'inflation targeting' by the South African authorities did have a significant impact on the average level of FDI inflow to the country. This has important implications for developing countries. A study of Akinboade et al (2006) stated that low inflation is a sign of internal economic stability in the country while high inflation rates reflect the inability of the government to balance its budget and the failure of the central bank to conduct appropriate monetary policy. Khan and Mitra (2014) studied data on FDI inflows into India over the period 1976-2012. The Granger-causality test results concluded that exchange rate and GDP statistically significantly influence FDI, whereas, inflation rate is insignificant variable to predict FDI inflows. Xaypanya, Rangkakulnuwat and Paweenawat (2015) studied the determinants of FDI in the ASEAN region using data over an eleven-year period (2000-2011) and found that while there 
are significantly positive effects of infrastructure facility and level of openness on FDI inflows into the ASEAN region, the inflation rate had a negative impact. The general conclusion on inflation is that it reduces it reduces returns on investments and thereby affects FDI inflows.

Abott and De Vita (2011) empirically examined the effect of exchange rate regimes on foreign direct investment (FDI) flows on a panel of 70 developing countries for the period 1985-2004, and found that developing countries with fixed or intermediate regimes significantly outperformed those with a flexible exchange rate system in attracting FDI flows. Chong and Tan (2008) studied four south East Asian economies found that there is a long-run co-movement between exchange rate and FDI. The study of Ang (2008) on the Malaysian economy supported the proposition that currency value depreciation is associated with greater FDI inflows. The research of Wafure and Nurudeen (2010) revealed that exchange rate depreciation is one of the main determinants of foreign direct investment in Nigeria. The research of Xing (2006) indicated that the devaluation of the yuan (renminbi) improved China's competitiveness in attracting FDI from Japan. Walsh and Yu (2010) detailed the relationship between exchange rate and foreign direct investment flow to host country. They argued that within an imperfect capital market, weaker currency in host country has positive impact on the inflow of FDI in that country as assets of host country become less expensive. On the other hand, the research of Lily et al (2014) on inflows of foreign direct investment (FDI) into ASEAN economies 1970-2011, using the ARDL approach found that there was significant long-run cointegration between exchange rate and FDI with a negative sign for the exchange rate coefficient implying currency appreciation, and moreover the direction of causality was between the exchange rate coefficient and

If investment projects are directed towards the tradable sector, a country's degree of openness to international trade is a relevant factor in the investment decision. Jordaan (2004) argues that the impact of openness on FDI depends on the type of investment. When investments are market-seeking, trade restrictions (and therefore less openness) can have a positive impact on FDI, as foreign firms that seek to serve local markets may decide to set up subsidiaries in the host country if it is difficult to import their products to the country. In contrast, multinational firms engaged in export-oriented investments may prefer to invest in a more open economy since increased imperfections that accompany trade protection generally imply higher transaction costs associated with exporting. Wheeler and Mody (1992) observe a strong positive support for the hypothesis in the manufacturing sector, but a weak negative link in the electronics sector. Kravis and Lipsey (1982), Culem (1988), Edwards (1990) find a strong positive effect of openness on FDI and Schmitz and Bieri (1972) obtain a weak positive link. Pärletun (2008) finds that trade openness is positive but statistically significant from zero. In ODI (1997), it is stated that while access to specific markets - judged by their size and growth - is important, domestic market factors are predictably 
much less relevant in export-oriented foreign firms. A range of surveys suggests a widespread perception that "open" economies encourage more foreign investment. Trade openness attracts export seeking FDI and the sharing of resources toward MNC growth.

A study by Kosekahyaoglu (2006) on the Turkish economy finds a unidirectional Granger causality from FDI to trade openness, and not from trade openness to FDI inflows. Results from other studies suggest either a complementary or a substitution relationship between trade openness and FDI inflows, depending on whether intermediate or final goods are being considered (Aydin, 2010). Most studies of this relationship indicate that the relationship is complementary (Kamath, 2008). In conclusion, although there are reasons that suggest both substitution and complementarity effects, the results almost point to a positive relationship between trade openness and FDI inflows.

\section{GDP and GDP per capita}

There is confusion in the literature on GDP and GDP per capita, which in many papers are referred to interchangeably. Gross Domestic Product (GDP) is the value of all market and some nonmarket goods and services produced within the geographic borders of a given country and is an indicator of the size of an economy; whereas GDP per capita is an indicator of the income level of a country and a rough indicator of a country's economic wellbeing and purchase power of its citizens (Callen (2008)). It is necessary to distinguish between the two as they represent prospects for FDI from different perspectives.

Bhasin et al. (1994) as well as Morrissey and Rai (1995), claim that the size of the domestic market, as well as the growth prospects of the recipient economy are given high consideration when foreign investors relocate production into the host country. Similarly, Scaperlanda and Mauer (1969) put forth the hypothesis that an FDI inflow responds positively to the recipient country's market size once it grows beyond a threshold level that is large enough to allow economies of scale and efficient utilization of resources. Chakrabarti, (2001) argues that the larger the market size in host country, the greater the opportunity for foreign direct investment inflow; as a large market is required for efficient utilization of resources and exploitation of economies of scale. Pärletun (2008) and Ang (2008) also find that GDP has a significant positive impact on FDI.

Jordaan (2004) mentions that FDI will move to countries with larger and expanding markets and greater purchasing power, where firms can potentially receive a higher return on their capital. Edwards (1990) and Jaspersen et al. (2000) use the inverse of income per capita as a proxy for the return on capital and conclude that real GDP per capita is inversely related to FDI/GDP, but Schneider and Frey (1985), Tsai (1994) find a positive relationship between the two variables. They argue that a higher GDP per capita implies better prospects 
for FDI in the host country. In a study on India, Indonesia and Pakistan, Azam (2010) finds that market potential proxied by GDP per capita, foreign debt, domestic investment, trade liberalization, and infrastructure are the significant economic determinants of inward FDI during 1971-2005. A recent study by Kurecic et al. (2015) attempted to examine the interdependence of GDP per capita and foreign direct investment in the transitional economies of Central and Eastern Europe. In their study, which used annual time series data over the years 1994 to 2013, the states examined were classified into three geopolitical groups; two groups of non-EU states and a third group of more recent EU states. The findings of the study revealed that FDI and GDP per capita were related based on evidence from 14 states out of 20 . In conclusion, market seeking FDI pursues both these factors.

\section{Infrastructure}

Soft infrastructure implies market oriented institutions, governance structures and such; hard means physical infrastructure (such as roads, telephone connections, airports, roads, fast distribution networks, electricity transmissions and railroads).

Wheeler and Mody (1992), studying the investment location decisions of U.S. firms examined the impact of infrastructure quality on investment in 42 developing countries over the period between 1982 and 1988 and found that quality of energy, communication and transport infrastructure have a highly significant positive impact on the volume of investment in the countries under study.

The availability of well-developed infrastructure will reduce the cost of doing business for foreign investors and enable them to maximize the rate of return on investment (Morriset, 2000).

Bakar et al. (2012), studying the Malaysian have pointed to the importance of both hard and soft infrastructure toward attracting FDI inflows. Chakrabarti et al (2012) examined the relationship between infrastructure and FDI in India between the year 2002 and 2007 and found that there is a positive relationship between physical infrastructure and FDI inflow, though this depended on the level of infrastructure. Behname (2012) studied the relationship between infrastructure and FDI flows in a cross-sectional data of Southern Asia countries between 1980 and 2009 and found that urban infrastructure impacts FDI positively. Fung et al (2005) researching which type of infrastructure (hard or soft) draws the attention of foreign investors and attracts FDI to China found that both soft and hard infrastructure have a significant positive effect on FDI inflow although soft infrastructures outpace hard infrastructure in attracting FDI. Seetanah (2009) studied Mauritius data (1981-2005) to examine the link between FDI and physical infrastructure in attracting FDI to the manufacturing and services sector of Mauritius. The result of the estimation showed manufacturing sector investors pay more atten- 
tion to physical infrastructure while services sector investors paid less attention to it. A study by Omezzine and Hakro (2011) to study the link between FDI flows and governance infrastructure in Mena Region countries found that governance infrastructure has a significant positive impact on FDI flows to the regions. Rehman et al (2011) studied the impact of infrastructure on FDI in Pakistan over the period 1975-2008 and found that infrastructure, and market size were positively related and exchange rate negatively related to FDI inflows in the short-run and in the long-run. Furthermore, poor infrastructure reduces the productivity of investments thereby discouraging inflows. Rehman, Ilyas, Alam \& Akram (2011) revealed that a strong positive impact of infrastructure in attracting foreign direct investment, in short and in long run, in case of Pakistan. A study by Ahmad, Ismail \& Norrdin (2015) suggested that infrastructure also had positive impact on FDI in Malaysia. The findings suggest that the reduction of business cost through improvement of infrastructure help to increase competitiveness in attracting FDI.

\section{Other factors related to an economy}

Fedderke and Romm (2006), identified both policy and non-policy factors that drive foreign direct investment across-borders. They referred to productmarket regulation, labor-market arrangements, corporate tax rates, openness, trade barriers, infrastructure and restriction on direct FDI as policy factors that drive FDI inflows. The research also categorized market size of recipient country as measured by GDP, transport cost, factor endowments, political and economic stability as non-policy factors. The role of taxes in attracting FDI over the years has been researched by Simmons, (2003), Karkinsky and Riedel, (2012), and Becker, Fuest and Riedel, (2012) using panel data of multinational institutions from various perspectives showed that corporate taxes in host country have significant negative effect on the flow of FDI. On the other hand, research by (Jones and Temouri, 2016) showed that corporate taxes have no significant effect on the flow of FDI. Sekkat and Veganzones-Varoudakis (2007) researching the determinants of foreign direct investment inflow, into three categories namely basic economic factors, trade and the exchange market policies and other aspects of the investment climate such as foreign exchange policy regime as well as trade liberalization and exchange rate volatility and find that host economy's business climate such as infrastructure, availability of skilled labor, incentive factors, political risk, economic factors, social factors, political stability, the role of institutions to enforce law and order are key drivers of foreign direct investment in foreign economies. In their work on the role of interest rate in attracting foreign direct investment using five Asian economies, Siddiqui and Aumeboonsuke (2014) argued that political stability is a vital determinant of FDI inflow. Hence, low political risk signals government commitment to protecting investors and has positive effect on FDI inflow. 


\section{Summary}

The importance of FDI to an economy is clear: it creates additional employment, technological progress, productivity improvements and economic growth. In summary, existing theories on FDI postulate actions for firms from the perspective of the MNC, which could be market seeking or horizontal FDI, resource seeking or vertical FDI or Efficiency seeking which could be restructuring operations overseas to achieve economies of scale or scope. While MNC motivation can be seen from these aspects, much empirical research has also been conducted on the determinants of FDI from the perspective of the host economy where there does not appear to be any theory. On the effect of some main determinants of FDI, there does not appear to be a consensus among researchers, on the effect of inflation in attracting FDI inflows. While inflation can be seen to be the outcome of macroeconomic policies followed by a government, investors may be looking for longer term prospects in the economy based on its location, market size, income levels and natural endowments. Generally, the impact of inflation on FDI is to affect investment decisions, through its effect on the return on investments. Empirical research on the impact of the exchange rate on FDI inflows suggests that in developing markets, investors seem to prefer currency depreciation so that their inward investments can have a higher purchase power in terms of local asset values; while in developed markets, currency appreciation is preferred by investors as it represents higher potential returns when converted into the investment currency. Although the overall conclusion from empirical research favours trade openness, it also gives us the insight that it depends on investor objectives: a higher level of trade openness does not favour FDI which is market seeking, but those which are more export oriented. Market size (represented by the value of Real GDP) is clearly important, as it represents future potential for expansion, growth and resource utilisation. On the other hand, Income levels, represented by Real GDP per capita are indicative of the purchasing power of citizens in the economy and are an indicator of what type of FDI investment is appropriate as an entry strategy for the market. Finally, both soft and hard infrastructure are important for higher FDI inflows; their relative importance depending on the type of activity the investor is in. Poor infrastructure, generally, increases operational costs and can reverse the return on investments, than originally envisaged.

A review of other important characteristics for an economy to receive higher FDI inflows, revealed that levels of taxation, political risk and social factors are also important considerations. 


\subsection{Research Design}

\subsection{Problem Statement}

The advantages of incoming FDI to developing countries are documented in research. As no previous research has been conducted to assess the common determinants of FDI on the economies of Ukraine, Belarus, Armenia, Russia, Moldova and Kazakhstan. After extensively reviewing previous research and alternative ways to study this problem, a positivist, deductive approach is chosen. Relying on factors identified in previous empirical research, this study analyzes the impact of market size, income level, infrastructure, inflation, exchange rate and openness on FDI inflows to these selected countries between 1990 to 2017. Analysis of these variables are expected to provide further statistical explanations of their relationship with the inflow of foreign direct investment in the region. This will enhance policy recommendations for the promotion of foreign direct investment in these countries. The model for research is specified as below in Table 2 below.

Table 2

Conceptual framework (created by Authors)

\begin{tabular}{|l|}
\hline Variables \\
\hline \hline Inflation \\
\hline \hline Exchange Rate \\
\hline \hline Openness
\end{tabular} \begin{tabular}{c}
$\begin{array}{c}\text { Foreign Direct } \\
\text { Investment (FDI) } \\
\text { inflow } \\
(1995-2017)\end{array}$ \\
\hline \hline Market Size \\
\hline Income Level
\end{tabular}

The relationship being tested is

FDI / GDP = f (inflation, GDP, GNI per capita, exchange rate, openness, infrastructure). 


\subsection{Data Sources}

The study is focused on analyzing the relationship between six independent variables identified from the literature review in six FSU countries: Ukraine, Belarus, Armenia, Russia, Moldova and Kazakhstan over the period 1990-2017. The sources of data collected for dependent and independent variables specific to each countries are summarized in the Table 3 below.

Table 3

Variables in the model and data sources

\begin{tabular}{|c|c|c|}
\hline Variables & Meaning & Data Source \\
\hline FDIGDP & $\begin{array}{l}\text { Net Foreign Direct Investment/Gross } \\
\text { Domestic Product }\end{array}$ & $\begin{array}{l}\text { World Bank's World } \\
\text { Leading Indicators base }\end{array}$ \\
\hline RGDP & $\begin{array}{l}\text { Real Gross Domestic Product } \\
\text { ( } 2010 \text { base) }\end{array}$ & $\begin{array}{l}\text { World Bank's World } \\
\text { Leading Indicators base }\end{array}$ \\
\hline RGNIPC & $\begin{array}{l}\text { Gross National Income per capita } \\
\text { ( } 2011 \text { base) }\end{array}$ & $\begin{array}{l}\text { World Bank's World } \\
\text { Leading Indicators base }\end{array}$ \\
\hline INFRA & $\begin{array}{l}\text { Fixed Line and Mobile subscriptions } \\
\text { per } 100 \text { people }\end{array}$ & $\begin{array}{l}\text { World Bank's World } \\
\text { Leading Indicators base }\end{array}$ \\
\hline EXRTO\$ & $\begin{array}{l}\text { Official Exchange Rate: local currency } \\
\text { units per US\$ }\end{array}$ & $\begin{array}{l}\text { IMF's International Finan- } \\
\text { cial Statistics base }\end{array}$ \\
\hline INF & $\begin{array}{l}\text { Inflation Rate based on Consumer } \\
\text { Price Index }\end{array}$ & $\begin{array}{l}\text { World Bank's World } \\
\text { Leading Indicators base }\end{array}$ \\
\hline OPEN & $\begin{array}{l}\text { (Export+lmport)/Gross Development } \\
\text { Product }\end{array}$ & $\begin{array}{l}\text { World Bank's World } \\
\text { Leading Indicators base }\end{array}$ \\
\hline
\end{tabular}

\subsection{Method of Analysis}

In econometric estimation, variables are required to be stationary. If the variables turn out to be a mix of $\mathrm{I}(0)$ and $\mathrm{I}(1)$, the appropriate method will be the ARDL (auto-regressive distributed lag ) approach. To capture the common and unique facts related to the inflow of FDI in the markets being studied, a panel cointegration approach is considered. This has the advantage of identifying long run processes (common to the entire market) and short run effects at work in each market. Panel unit root tests are conducted on each variable in the model to ensure regression estimations are effected with stationary variables. Panel cointegration tests are performed to test for the presence of cointegration. 


\subsection{Data Analysis and Findings}

\subsection{Data Inspection}

After inspection of the data on variables in the analysis, RGDP, RGNIPC and INFRAFM are natural logged (prefixed with $L$ ) to adjust for the variations. Details of the variables for all countries is presented in Appendix 1. The mean and standard deviation of data are as in Table 4 below.

Table 5 below, ranks the values for the various economies for each variable in ascending order.

Table 4

Mean and standard deviation of data

\begin{tabular}{|l|c|c|c|c|c|c|c|}
\hline \multicolumn{1}{|c|}{ Statistic } & FDIGDP & INF & LEXRTO\$ & LRGNIPC & LINFRAFM & LRGDP & OPEN \\
\hline Mean & 4,231 & 29,298 & 2,741 & 9,040 & 4,089 & 24,707 & 92,939 \\
\hline Median & 3,397 & 10,052 & 2,963 & 9,011 & 4,369 & 24,849 & 93,353 \\
\hline Maximum & 13,013 & 709,346 & 6,361 & 10,113 & 5,320 & 28,165 & 157,974 \\
\hline Minimum & 0,105 & $-1,404$ & $-6,766$ & 7,681 & 2,456 & 21,934 & 46,193 \\
\hline Std. Dev. & 3,117 & 76,669 & 2,771 & 0,679 & 0,958 & 1,903 & 29,192 \\
\hline Observations & 138 & 138 & 138 & 138 & 138 & 138 & 138 \\
\hline
\end{tabular}

Source: Authors' work

Table 5

Rankings of the various economies by variable (ascending order)

\begin{tabular}{|l|c|c|c|c|c|c|c|}
\hline \multicolumn{1}{|c|}{ Country } & FDIGDP & INF & OPEN & LRGDP & LRGNIPC & LEXRTO $\$$ & LINFRAFM \\
\hline Armenia & 4 & 1 & 2 & 2 & 2 & 1 & 1 \\
\hline Belarus & 2 & 6 & 6 & 3 & 4 & 6 & 3 \\
\hline Kazakhstan & 6 & 2 & 3 & 4 & 5 & 3 & 4 \\
\hline Moldova & 5 & 3 & 5 & 1 & 1 & 2 & 2 \\
\hline Russ Fed & 1 & 5 & 1 & 6 & 6 & 4 & 6 \\
\hline Ukraine & 3 & 4 & 4 & 5 & 3 & 5 & 5 \\
\hline
\end{tabular}

Source: Authors' work 
Table 5 shows that the larger countries, have better infrastructure, higher income levels. Inflation was highest in Belarus, while currency depreciation was highest in Belarus and Ukraine. Belarus also had the highest level of openness. Finally, Kazakhstan and Moldova had the highest level of FDI inflows in relation to GDP and the Russian Federation, the lowest.

\subsection{Data Analysis}

The data consists of observations for six countries from 1995 to 2017 (22 years; in the years upto 1995 after the transition in 1992, figures were in another sphere as transformation processes were taking root from a centrally planned economy to individually run market economies to various degrees); also, some data are not available in the period making it an unbalanced panel. Eviews 9.5 is used for estimations. The variables specified in the model for estimation (Table 2) are tested for stationarity using the panel unit root test. Stationarity of the variables is supported as follows: FDIGDP is I(0), LGNIPC is I(1), LINFRAFM is I(1), LEXRTO $\$$ is I(0), INF is I(0), OPEN is I(0), L(RGDP) is I(1). The details are in Appendix 1 . As the variables are a mix of $\mathrm{I}(0)$ and $\mathrm{I}(1)$, the ARDL method is the appropriate one for estimations. To test long run and short run relationships the estimations are based on panel cointegration. The results of panel cointegration tests applied on the variables (FDI/GDP, INF, OPENNESS, LEXROTO\$OPEN, LOGINFRAFM LOGRGDP LOGRGNIPC) are attached in Appendix 2.

\subsection{Interpretation of results}

The long run relationship shows that higher FDI inflows in relation to GDP over the whole period are associated with periods of higher inflation, better infrastructure, and smaller markets, though the signs of exchange rate (negative),openness (negative), income levels (positive) point to the general trend in the data though these are not statistically significant. The short run equation relating to changes in the independent variables validate the long run equation and show the direction of causality of the changes in the independent variables on changes in the dependent variable with change in the inflation rate (positive and significant), infrastructure and economic growth (DLRGDP), (positive and significant), lower income levels (negative and significant), openness and change in exchange rate (negative but not significant) being good drivers of change in the ratio of FDI/GDP.

The details of the short run outputs for each country are in Appendix 3 . In the short run, the causality in most markets were mixed. The results of long run and short run effects are summarized in Table 7 below. 
Table 6

\section{Estimation results of ARDL Model}

Dependent Variable: D (FDIGDP)

Method: ARDL

Date: $07 / 23 / 19$ Time: $13: 18$

Sample: 19962017

Included observations: 132

Dependent lags: 1 (Fixed)

Dynamic regressors (1 lag, fixed): INF OPEN LEXRTO\$ LINFRAFM LRGDP LGNIPC

Fixed regressors: $\mathrm{C}$

\begin{tabular}{|c|c|c|c|c|}
\hline Variable & Coefficient & Std. Error & t-Statistic & Prob.* \\
\hline & \multicolumn{4}{|c|}{ Long Run Equation } \\
\hline INF & 0,079224 & 0,018872 & 4,198052 & 0,0001 \\
\hline OPEN & $-0,027903$ & 0,027254 & $-1,023807$ & 0,3089 \\
\hline LEXRTO\$ & $-0,350510$ & 0,344763 & $-1,016669$ & 0,3122 \\
\hline LINFRAFM & 2,772973 & 0,662335 & 4,186663 & 0,0001 \\
\hline LRGDP & $-9,160902$ & 4,919292 & $-1,862240$ & 0,0661 \\
\hline \multirow[t]{2}{*}{ LGNIPC } & 0,781589 & 5,158038 & 0,151528 & 0,8799 \\
\hline & \multicolumn{4}{|c|}{ Short Run Equation } \\
\hline COINTEQ01 & $-0,739679$ & 0,072572 & $-10,19235$ & 0,0000 \\
\hline $\mathrm{D}(\mathrm{INF})$ & 0,022700 & 0,004301 & 5,277462 & 0,0000 \\
\hline D(OPEN) & $-0,029800$ & 0,028642 & $-1,040424$ & 0,3011 \\
\hline D(LEXRTO\$) & $-3,612097$ & 4,209936 & $-0,857993$ & 0,3933 \\
\hline D(LINFRAFM) & 6,246148 & 3,245148 & 1,924765 & 0,0576 \\
\hline $\mathrm{D}(\mathrm{LRGDP})$ & 49,72394 & 14,95211 & 3,325546 & 0,0013 \\
\hline D(LGNIPC) & $-51,55471$ & 19,38409 & $-2,659640$ & 0,0094 \\
\hline $\mathrm{C}$ & 159,0206 & 16,29852 & 9,756749 & 0,0000 \\
\hline \multicolumn{5}{|c|}{ Mean dependent } \\
\hline var & 0,034543 & \multicolumn{2}{|c|}{ S. D. dependent var } & 2,606450 \\
\hline S. E. of regression & 1,877813 & \multicolumn{2}{|c|}{ Akaike info criterion } & 3,854936 \\
\hline Sum squared resid & 296,1993 & \multirow{2}{*}{\multicolumn{2}{|c|}{$\begin{array}{l}\text { Schwarz criterion } \\
\text { Hannan-Quinn criter }\end{array}$}} & 5,000383 \\
\hline Log likelihood & $-211,9906$ & & & 4,320417 \\
\hline
\end{tabular}


Table 7

Summary of long run and short run effects in various economies

\begin{tabular}{|c|c|c|c|c|c|c|c|c|}
\hline Country & $\begin{array}{l}\text { Long run causal- } \\
\text { ity: }\end{array}$ & \multicolumn{7}{|c|}{$\begin{array}{l}\text { Short run significance } \\
\text { (D stands for Difference) }\end{array}$} \\
\hline Variable & $\begin{array}{l}\text { INF, INFRAFM, } \\
\text { RGDP }\end{array}$ & $\underset{\substack{\infty \\
\searrow}}{\stackrel{0}{z}}$ & $\underset{\square}{\stackrel{\overparen{I}}{Z}}$ & $\begin{array}{l}\widehat{\widehat{Z}} \\
\stackrel{u}{0} \\
\stackrel{0}{0}\end{array}$ & 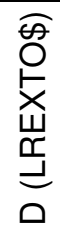 & 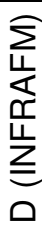 & 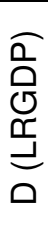 & 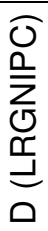 \\
\hline Armenia & $+{ }^{\star \star \star},+{ }^{\star \star *},-{ }^{*}$ & Так &,$+{ }^{* \star *}$ & $-{ }^{* * *}$ & - & + & + & - \\
\hline Belarus & $+{ }^{* \star *},+{ }^{* \star *},-{ }^{\star}$ & Так &,$+{ }^{* \star *}$ &,$+{ }^{* \star *}$ & $-{ }^{*}$ & + & + & - \\
\hline Kazakhstan & $+^{* \star *},+{ }^{* \star *},-^{\star}$ & Так &,$+^{* \star *}$ &,$-^{* * *}$ & + & + & + & - \\
\hline Moldova & $+{ }^{* \star *},+{ }^{\star \star *},-{ }^{\star}$ & Так &,$+{ }^{* * *}$ & + & - & + & + & - \\
\hline Russia & $+^{\star * \star},+^{\star \star *},-{ }^{\star}$ & Так &,$+^{* \star *}$ &,$-^{* \star *}$ & - & + & + & - \\
\hline Ukraine & $+{ }^{\star \star *},+{ }^{\star \star *},-{ }^{\star}$ & Так &,$+{ }^{* * *}$ &,$+{ }^{* * *}$ & - & + & + & - \\
\hline
\end{tabular}

*, ** , ** significant at the $10 \%, 5 \%$ and $1 \%$ levels, respectively

$+/$ - stands for higher/lower of significant coefficients

Source: Authors'work

The effect of the long run and average short run equations are captured individually for each market in the above table. The overall long run equation for all 6 markets is valid individually for all six markets and shows that FDI inflows are related to inflation and lower openness (coefficients are positive and significant (at the 1\% level)) and the coefficient of market size is significant (at the $10 \%$ level). However, the average short run equation again shows that inflation has been increasing in all the markets.

\section{Chapter 5: Discussion}

In the models estimated, with the six independent variables (inflation, openness, currency changes, infrastructure, income levels and market size) the coefficients of three variables showed long run significance in explaining the dependent variable (FDI/GDP). Higher FDI flows as a percentage of market (GDP), have taken place in markets with better infrastructure but lower size but characterized by higher inflation. The signs of the coefficients of exchange rates, openness are both negative and that of income levels is positive, though they are not 
significant. The short run effects represent changes in the independent variables influencing the changes in the ratio of FDI to GDP, while the long run equation captures the relationship across all the markets. Next the implications of each independent variable used for estimation of the impact on FDI is discussed with respect to previous research findings so that implications for Ukraine and five other FSU countries can be assessed.

\section{Inflation (INF)}

While studies by Andinuur(2013), Faroh and Shen(2015), Xaypanya, Rangkakulnuwat and aweenawat (2015), found that lower inflows attracts higher FDI inflows, the study by Obiamaka et al. (2011) and Omankhanlen's (2011) found that it had no effect on FDI inflows. In this study, the coefficient of the long run equation was significant and positive pointing to the inflationary macroeconomic conditions in these markets. In this study, in the short run, the coefficient of inflation had a positive sign for all the markets: Armenia, Belarus, Kazakhstan, Moldova, Russia and Ukraine.

\section{EXchange rates (EXRTO\$)}

While the study by Abott and De Vita(2011), found the relevance of fixed exchange rate regimes, in attracting higher FDI flows, studies by Wafure and Nurudeen (2010), Xing(2006), Walsh and Yu(2010) found that exchange rate depreciation was important, while a study by Lily et al(2014) found that exchange rate appreciation was important. In this study, in the short run, the coefficient of exchange rate had a negative sign significantly only for Belarus.

\section{Trade openness (OPEN)}

Jordaan (2004) argued that market-seeking companies look for more closedness, while export-seeking firms seek more openness. When trade restrictions are higher foreign firms have to resort to FDI to access local markets, while the presence of higher openness and availability of lower cost local resources may attract more FDI in the case of export oriented companies. These arguments are supported by the research of Wheeler and Mody(1992), Kravis and Lipsey (1982), Culem (1988), Edwards (1990) and Kosekahyaoglu (2006). There are also arguments of bi-directional causality.

In this study, in the short run, the coefficient of openness was negative and significant for Armenia, Kazakhstan and Russia and positive and significant for Kazakhstan and Belarus 


\section{Infrastructure (INFRAFM)}

Studies by Chakrabarti et al (2012), Behname (2012), Fung et al (2005) point to the higher FDI inflows attracted by countries with better infrastructure. Bakar et al. (2012), Seetanah(2009) differentiated between hard (physical) and soft infrastructure (market based institutional framework) and discussed their relevance. A study by Omezzine and Hakro (2011) found the importance of governance structures in attracting FDI. These findings are in line with research by Wheeler and Mody (1992) Babatunde (2011), Essia and Onyema (2012). In this study, the coefficient of infrastructure was positive and significant in both models pointing to the importance of the infrastructure variable. In the short run, the coefficient of the change in infrastructure was negative but not significant in both models, pointing to the need for more investment in infrastructure.

\section{Market Size (GDP)}

Chakrabarti, (2001). Pärletun (2008) and Ang (2008) also find that the size of the market has a significant positive impact on FDI. The argument being that the larger the market size in host country, gives the investor opportunities for efficient utilization of resources and exploitation of economies of scale. In this study, the coefficient of size was positive but not significant in all markets. This points to the positive effect that economic growth has on attracting FDI.

\section{Income level (GNIPC)}

Although Jordaan (2004), Schneider and Frey (1985), Tsai (1994), Azam (2010) states FDI will move to countries with larger and expanding markets and greater purchasing power, where firms can potentially receive a higher return on their capital. On the other hand, studies by Edwards (1990) and Jaspersen et al. (2000) imply that a lower GDP per capita implies better prospects for FDI in the host country. This is also evident from the study by Kurecic et al. (2015) of the relationship between income levels and FDI in the transitional economies of Central and Eastern Europe, which found a greater attraction of FDI to markets with lower income implying that the attraction for FDI is greater here with investors seeing greater potential in these markets. In this research, the coefficient of income levels was negative and significant in one model pointing to the area where investment was attracted most. In the short run, again the coefficient of the change in income levels was negative but not significant pointing to investors seeing better prospects in markets with lower income levels.

These findings, compared and contrasted with previous research give rise to important considerations for policy formulation for these countries. Although so 
far, the smaller countries with better infrastructure but higher inflation appear to have attracted a higher proportion of FDI in relation to GDP, the importance of exchange rate adjustments, openness and income levels also become clear. Such FDI is of the nature of resource seeking FDI, although the potential of the larger markets attracts market seeking and efficiency seeking FDI through larger size, more efficient utilization of resources and exploitation of economies of scale. Good macroeconomic management to lower inflation, stabilize exchange rates, increase openness, improve infrastructure will lead to benefits for all the economies, though this is a difficult process given the problems of restructuring entire economies from the previous mind-set of central planning to the current market orientation, albeit to different degrees in the various economies. The differentiation between hard and soft infrastructure is important, and depending on the type of FDI an economy, wants to attract policies will need to be implemented. In addition, the general wisdom is that economies must move to higher openness for increased international competitiveness.

In summary, the policies which will help these countries bring in higher FDI inflows and aid rapid economic growth are:

(i) monetary policy control. Empirical research has pointed to the importance of a stable macroeconomic environment (low inflation, interest rates, stable exchange rates) so that investors can get a better real return on their investments. Although the equations show a different short term trend, the reasoning is that a good part of the inflation in FSU economies, even at this stage, is due to the continuous price re-structuring process between cost of goods and services in the old Centrally Planned Economy (particularly domestic goods and services) and the new Market Economy, which require a longer horizon to stabilize.

(ii) Investment in infrastructure: Empirical research has pointed to the importance of better soft infrastructure (market oriented institutions, financial institutions, corporate governance), and hard infrastructure (roads, telephones, airports, transport networks, electricity distribution); these reduce operational costs for investors and are much desired. The government needs to channel funds into infrastructure development (hard and soft) to improve infrastructure.

(iii) the relevance of market size in the equations points to the nature of FDI attracted into FSU countries: this is basically 'market seeking FDI' given the domestic demand for modern western style goods and services in FSU countries.

(iv) in the case of Ukraine, the openness variable has a positive sign, meaning higher import export trade facilitates inflows of FDI. Here sectoral analysis (agricultural, manufacturing, trade, service) is required to identify appropriate policies for higher investment and economic growth. The Auto industry is a particular area of focus: this is the backbone of industry in every major economy with the huge employment it creates directly and indirectly via supply chains. Moreover, the initiative toward clean energy provides additional new opportunities in every area. Ukraine has large resources of human capital: educated and 
skilled labour. With a proper combination of tariffs and tax-exemptions, in selected areas, these present a vast area for economic expansion and growth.

(v) Finally, policies need to be aligned with FDI promotion ie easy stay permits for foreign investors, company incorporation, reduction in regulations, capital repatriation laws, tax-exemptions for foreign investments (FDI) in key sectors in the real economy (agriculture, manufacturing, industry).

\section{Chapter 6: Conclusion}

The aim of this research was to ascertain the determinants of FDI in six FSU countries post transformation, in the period 1995-2017. The estimated model showed the importance and relevance of the independent variables chosen for estimation: openness, market size, inflation, infrastructure, income level and currency appreciation in explaining the dependent variable (FDI/GDP) or changes in it in the various models, albeit to a different extent. Higher FDI flows as a percentage of market (GDP), are concomitant with higher inflation, better infrastructure and smaller markets with lower openness, currency depreciation and higher income levels. The finding on inflation is not anomalous given that these markets are transforming from price structures in previous centrally planned economies to their current market orientation to various degrees.

Market characteristics apart, good macroeconomic management to lower inflation and stabilize exchange rates can only lead to benefits for all the economies. These deliver a higher degree of certainty in returns for investors. The differentiation between hard and soft infrastructure is also important; good physical infrastructure lowers costs and soft infrastructure eases operations and improves governance issues, vital for attracting FDI. The general wisdom is also that economies must move to higher openness for increased international competitiveness.

FDI can not only create employment, bring about higher production and exports but also intangibly benefit the economy through introduction of improved technologies, development of local human resources, skills transfers, higher taxes to government and these effects need to be taken into account in formulating policy changes necessary for higher economic activity all of which can contribute to sustainable economic growth. The rationalization of internal legal frameworks, simplification of rules for investors, improvements in the working of the banking and services sector, assured repatriation of profits are all important matters which can enhance FDI inflows for all markets.

On the one hand, FSU markets present opportunities for market seeking FDI through the potential demand for western style products and services, and on the other hand, also present opportunities for resource seeking and vertical 
FDI, through the availability of educated and skilled labour forces. The six economies in the FSU countries in this study, are all transformation economies countries which need capital for growth and the most appropriate policy for a particular market depends on its structure, the supply of labour and other resources, and linkages between sectors and economies.

Each economy will thus need to analyse its present structure (whether predominantly commodity based, manufacturing, agricultural, industrial or service orientated), assess its resources (stock of labour, intellectual capital and natural resources), the linkages between sectors and economies and its vision for the future. The intangible benefits of FDI such as improved technologies, development of local human resources, skills transfers, higher taxes to government, prompts on policy changes necessary for higher economic activity need to be taken into account in formulating policies. The rationalization of internal legal frameworks, simplification of rules for investors, improvements in the working of the banking and services sector, assured repatriation of profits are important matters which enhance FDI are common for all markets. Policies to promote internal investment will vary from market to market depending on these matters and whether it is attracting market seeking or horizontal FDI; resource seeking or vertical FDI, or efficiency seeking FDI. Thereafter policy makers can devise suitable policies with relative emphasis on various actions, consistent with reaching its planned targets.

\section{Limitations and recommendations for further research}

The UNCTAD and World Bank databases have made available much of the data for this study. While the variables chosen for the analysis all proved to be relevant, deeper analysis would require reliable data and complete datasets on other determinants such as labor cost, economy wide power consumption, corporate tax rate, corruption, natural resources, effectiveness of rule of law and political risk. In depth country based studies with the same variables tested for linkages with other sectors, economies and economic growth will doubtless provide further insights. These are some of the directions which can be taken in future studies. 


\section{Appendix 1}

The data on variables in the analysis is inspected individually to look at individual and overall market characteristics regarding that variable

Figure 1a

Foreign Direct Investment (FDI) as a ratio of GDP\% (1992-2017)

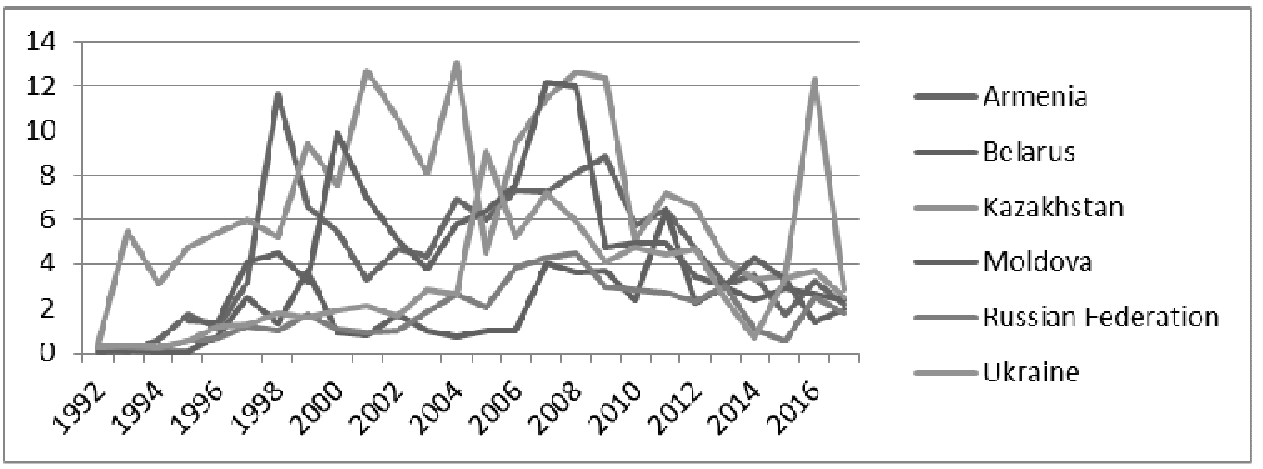

Descriptive statistics

\begin{tabular}{|l|c|c|c|c|c|c|}
\hline Country & Armenia & Belarus & Kazakhstan & Moldova & Russ Fed & Ukraine \\
\hline Mean & 4.53 & 1.97 & 7.17 & 5.06 & 1.83 & 2.93 \\
\hline Rank & 4 & 2 & 6 & 5 & 1 & 3 \\
\hline St Dev & 2.90 & 1.54 & 3.67 & 3.02 & 1.25 & 2.24 \\
\hline Rank & 4 & 2 & 6 & 5 & 1 & 3 \\
\hline
\end{tabular}

Source: Authors used UNCTAD/World Development Indicators and World Investment Report online data

The average FDI/GDP ratio over the period 1995-2017 was highest for Kazhakstan and Moldova (more than 5\%) and lowest for the Russian Federation; though the variability of inflows was also high for Kazhakstan and Moldova. 
Inflation rate (INF)

Figure $1 b$

Inflation based on CPI in the six countries (1995-2017)

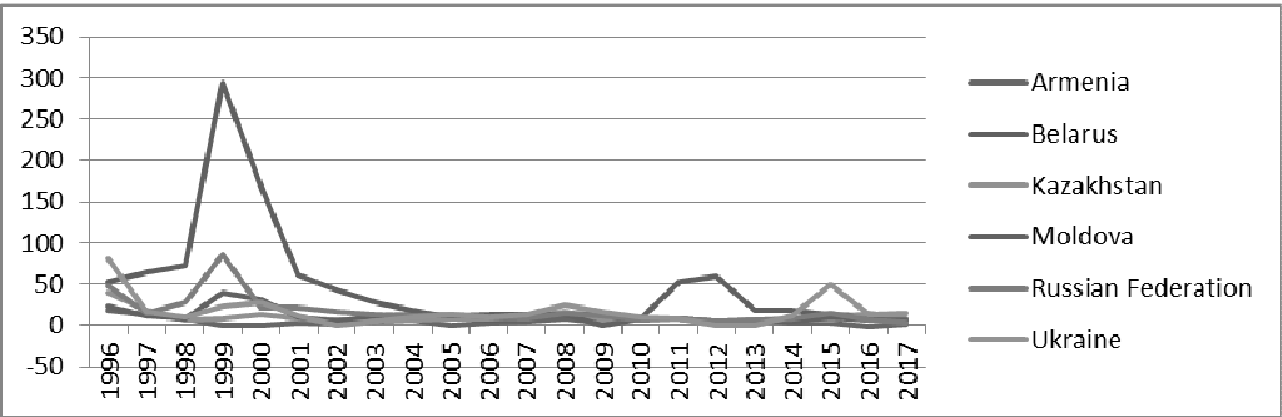

Source: Authors used UNCTAD/World Development Indicators and World Investment Reports online data

Descriptive statistics

\begin{tabular}{|l|c|c|c|c|c|c|}
\hline Country & Armenia & Belarus & Kazakhstan & Moldova & Russ Fed & Ukraine \\
\hline Mean & 4.90 & 47.43 & 10.30 & 11.58 & 17.13 & 16.73 \\
\hline Rank & 1 & 6 & 2 & 3 & 5 & 4 \\
\hline St Dev & 4.80 & 66.22 & 7.33 & 9.06 & 18.04 & 17.75 \\
\hline Rank & 1 & 6 & 2 & 3 & 5 & 4 \\
\hline
\end{tabular}

In the period under study 1995-2017, average inflation was high in Belarus, the Russian Federation and Ukraine (>15\%) and lower in other countries (Armenia, lowest at $4.9 \%$ ). Variability of exchange rates was highest in Belarus and Russia, followed by Ukraine. 


\section{Exchange rate changes year to year}

\section{Figure 1c}

Exchange Rate changes year to year\% (1995-2017)

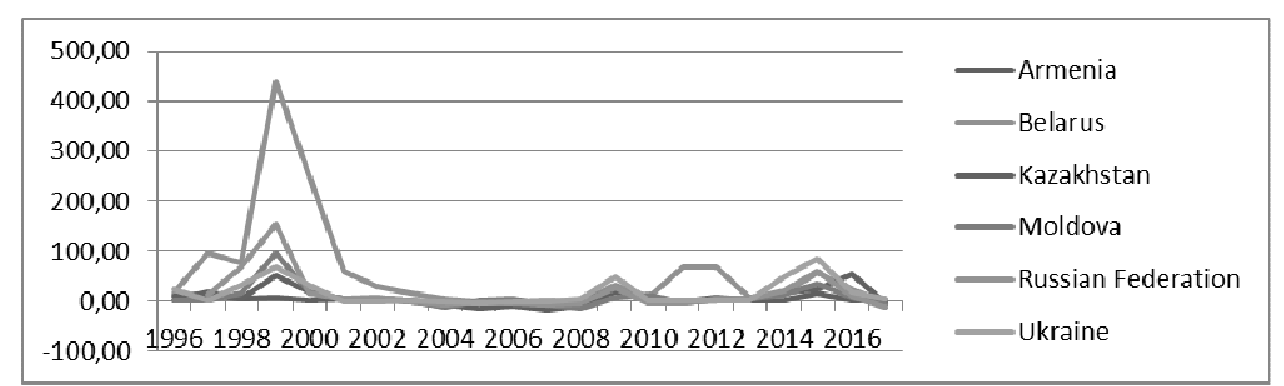

Descriptive statistics

\begin{tabular}{|l|c|c|c|c|c|c|}
\hline Country & Armenia & Belarus & Kazakhstan & Moldova & Russ Fed & Ukraine \\
\hline Mean & 1.20 & 57.20 & 9.04 & 8.28 & 16.28 & 16.31 \\
\hline Rank & 1 & 6 & 3 & 2 & 4 & 5 \\
\hline St Dev & 9.27 & 102.22 & 17.09 & 22.20 & 37.53 & 25.33 \\
\hline Rank & 1 & 6 & 2 & 3 & 5 & 4 \\
\hline
\end{tabular}

Source: Authors used UNCTAD/World Development Indicators and World Investment Reports online data

On average, the currencies of all six countries depreciated with the highest average depreciation over the period 1995-2017 in Belarus, Ukraine and the Russian Federation. Variability of exchange rates was highest in Belarus and Russia, followed by Ukraine. 


\section{Openness (OPEN)}

Figure $1 d$

Openness (OPEN) (1992-2017)

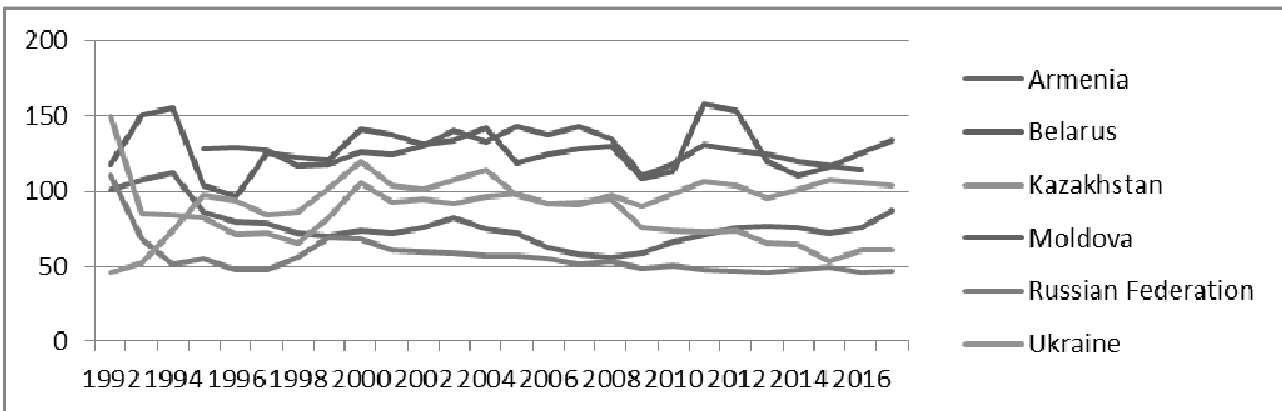

Descriptive statistics

\begin{tabular}{|l|c|c|c|c|c|c|}
\hline Country & Armenia & Belarus & Kazakhstan & Moldova & Russ Fed & Ukraine \\
\hline Mean & 76.67 & 127.65 & 82.67 & 126.87 & 56.03 & 94.94 \\
\hline Rank & 2 & 6 & 3 & 5 & 1 & 4 \\
\hline
\end{tabular}

Source: Authors used UNCTAD/World Development Indicators and World Investment Report online data

The highest level of openness in the period 1992-2017 was in Belarus and Moldova (above 100\%) and lowest in the Russian Federation. Openness is a measure of the level of international trade flows. 


\section{Market size Log of (RGDP)}

\section{Figure 1e}

\section{Market size Log of (RGDP) (1995-2017)}

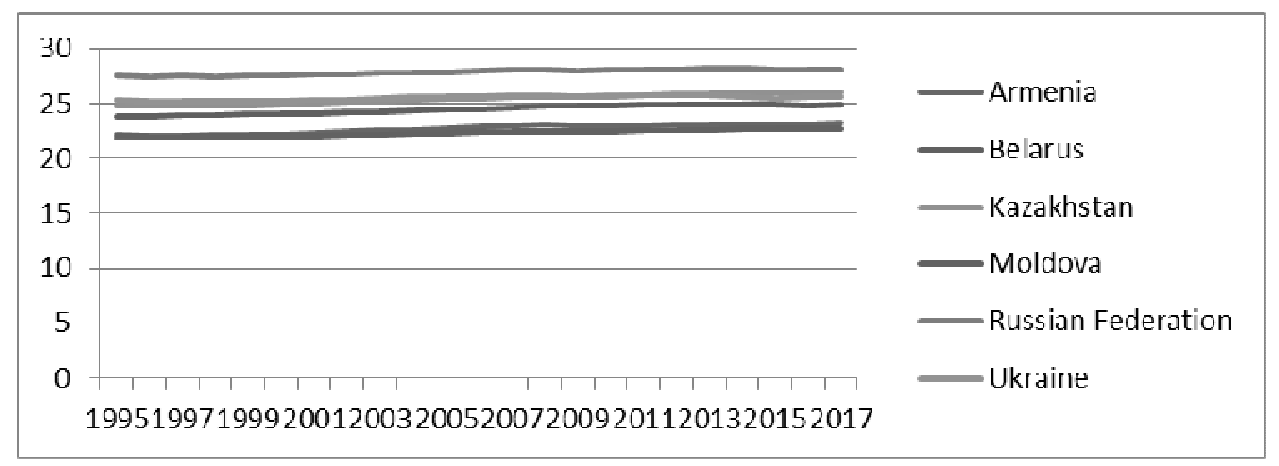

Descriptive Statistics

\begin{tabular}{|l|c|c|c|c|c|c|}
\hline Country & Armenia & Belarus & Kazakhstan & Moldova & Russ Fed & Ukraine \\
\hline Mean & 22.68 & 24.45 & 25.42 & 22.34 & 27.86 & 25.49 \\
\hline Rank & 2 & 3 & 4 & 1 & 6 & 5 \\
\hline
\end{tabular}

Source: Authors used UNCTAD/World Development Indicators and World Investment Report online data

Market size is considered an important variable for market-seeking FDI. The largest markets in the ten countries are the Russian Federation and Ukraine, while Moldova is the smallest. 


\section{Income level (Real GNI/capita)}

Figure $1 f$

\section{GNI Per Capita (1990-2017)}

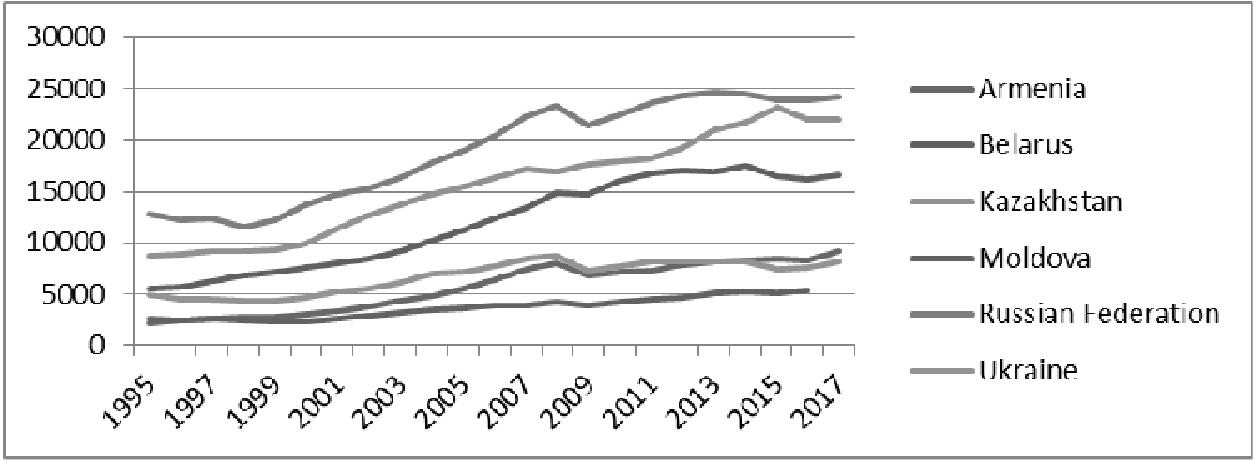

Descriptive Statistics

\begin{tabular}{|l|c|c|c|c|c|c|}
\hline Country & Armenia & Belarus & Kazakhstan & Moldova & Russ Fed & Ukraine \\
\hline Mean & 5693 & 11954 & 15494 & 3663 & 18993 & 6691 \\
\hline Rank & 2 & 4 & 5 & 1 & 6 & 3 \\
\hline
\end{tabular}

Source: Authors used UNCTAD/World Development Indicators and World Investment Report online data

GNI per capita is a measure of the income level and purchasing power capacity of a country. Average real GNI per capita (2011\$) over the period 1995-2017 was highest in the Russian Federation, Kazakhstan, and Belarus $(>\$ 10,000)$ and lowest in Moldova $(<\$ 5,000)$. 


\section{Infrastructure (Log of INFRAFM)}

\section{Figure $1 g$}

Infrastructure (1992-2017)

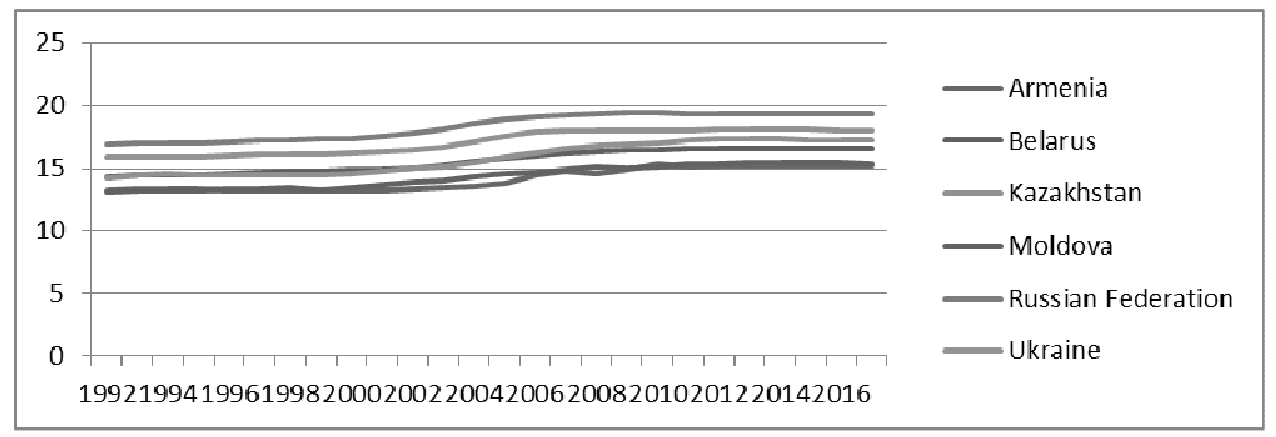

Descriptive Statistics

\begin{tabular}{|l|c|c|c|c|c|c|}
\hline Country & Armenia & Belarus & Kazakhstan & Moldova & Russ Fed & Ukraine \\
\hline Mean & 14.11 & 15.59 & 15.78 & 14.33 & 18.35 & 17.10 \\
\hline Rank & 1 & 3 & 4 & 2 & 6 & 5 \\
\hline
\end{tabular}

Source: Author used UNCTAD/World Development Indicators online data

Infrastructure is important for foreign investors. Here the sum of Fixed telephone line and Mobile cell subscriptions per 100 persons is used as a measure of infrastructural development of a country as suggested. In terms of this measure of the infrastructure, the Russian Federation and Ukraine have the highest levels of infrastructure. 


\section{Appendix 2}

\section{Panel Unit Root tests}

Panel unit root test: Summary

Series: FDIGDP

Date: 06/07/19 Time: 09:20

Sample: 1995-2017

Exogenous variables: Individual effects

User-specified lags: 1

Newey-West automatic bandwidth selection and Bartlett kernel

Balanced observations for each test

\begin{tabular}{|c|c|c|c|c|}
\hline Method & Statistic & Prob. ${ }^{\star *}$ & $\begin{array}{l}\text { Cross- } \\
\text { sections }\end{array}$ & Obs \\
\hline \multicolumn{5}{|c|}{ Null: Unit root (assumes common unit root process) } \\
\hline Levin, Lin \& Chu t* & $-1,08105$ & 0,1398 & 6 & 126 \\
\hline \multicolumn{5}{|c|}{ Null: Unit root (assumes individual unit root process) } \\
\hline Im, Pesaran and Shin W-stat & $-1,74900$ & 0,0401 & 6 & 126 \\
\hline ADF - Fisher Chi-square & 18,8531 & 0,0921 & 6 & 126 \\
\hline PP - Fisher Chi-square & 32,9261 & 0,0010 & 6 & 132 \\
\hline
\end{tabular}

** Probabilities for Fisher tests are computed using an asymptotic Chisquare distribution. All other tests assume asymptotic normality.

Panel unit root test: Summary

Series: D (LGNIPC)

Date: 06/07/19 Time: 09:13

Sample: 1995-2017

Exogenous variables: Individual effects

User-specified lags: 1

Newey-West automatic bandwidth selection and Bartlett kernel

\begin{tabular}{|c|c|c|c|c|}
\hline Method & Statistic & Prob. ${ }^{* *}$ & $\begin{array}{l}\text { Cross- } \\
\text { sections }\end{array}$ & Obs \\
\hline \multicolumn{5}{|c|}{ Null: Unit root (assumes common unit root process) } \\
\hline Levin, Lin \& Chut* & $-2,30500$ & 0,0106 & 6 & 119 \\
\hline \multicolumn{5}{|c|}{ Null: Unit root (assumes individual unit root process) } \\
\hline Im, Pesaran and Shin W-stat & $-1,84929$ & 0,0322 & 6 & 119 \\
\hline ADF - Fisher Chi-square & 20,1021 & 0,0652 & 6 & 119 \\
\hline PP - Fisher Chi-square & 40,0569 & 0,0001 & 6 & 125 \\
\hline
\end{tabular}

** Probabilities for Fisher tests are computed using an asymptotic Chisquare distribution. All other tests assume asymptotic normality. 
Panel unit root test: Summary

Series: LEXRTO\$

Date: 06/07/19 Time: 09:15

Sample: 1995-2017

Exogenous variables: Individual effects

User-specified lags: 1

Newey-West automatic bandwidth selection and Bartlett kernel

\begin{tabular}{|c|c|c|c|c|}
\hline Method & Statistic & Prob.** & $\begin{array}{l}\text { Cross- } \\
\text { sections }\end{array}$ & Obs \\
\hline \multicolumn{5}{|c|}{ Null: Unit root (assumes common unit root process) } \\
\hline Levin, Lin \& Chut ${ }^{*}$ & $-3,61039$ & 0,0002 & 6 & 125 \\
\hline \multicolumn{5}{|c|}{ Null: Unit root (assumes individual unit root process) } \\
\hline Im, Pesaran and Shin W-stat & $-1,78098$ & 0,0375 & 6 & 125 \\
\hline ADF - Fisher Chi-square & 23,4239 & 0,0243 & 6 & 125 \\
\hline PP - Fisher Chi-square & 12,6853 & 0,3923 & 6 & 131 \\
\hline
\end{tabular}

** Probabilities for Fisher tests are computed using an asymptotic Chisquare distribution. All other tests assume asymptotic normality.

Panel unit root test: Summary

Series: INF

Date: 06/07/19 Time: 09:18

Sample: 1995-2017

Exogenous variables: Individual effects

User-specified lags: 1

Newey-West automatic bandwidth selection and Bartlett kernel

Balanced observations for each test

\begin{tabular}{|c|c|c|c|c|}
\hline Method & Statistic & Prob. ${ }^{* *}$ & $\begin{array}{l}\text { Cross- } \\
\text { sections }\end{array}$ & Obs \\
\hline \multicolumn{5}{|c|}{ Null: Unit root (assumes common unit root process) } \\
\hline Levin, Lin \& Chut $^{*}$ & 21,5818 & 1,0000 & 6 & 126 \\
\hline \multicolumn{5}{|c|}{ Null: Unit root (assumes individual unit root process) } \\
\hline Im, Pesaran and Shin W-stat & $-5,41705$ & 0,0000 & 6 & 126 \\
\hline ADF - Fisher Chi-square & 51,7883 & 0,0000 & 6 & 126 \\
\hline PP - Fisher Chi-square & 859,110 & 0,0000 & 6 & 132 \\
\hline
\end{tabular}

** Probabilities for Fisher tests are computed using an asymptotic Chisquare distribution. All other tests assume asymptotic normality. 
Panel unit root test: Summary

Series: D (LINFRAFM)

Date: 06/07/19 Time: 09:19

Sample: 1995-2017

Exogenous variables: Individual effects

User-specified lags: 1

Newey-West automatic bandwidth selection and Bartlett kernel

Balanced observations for each test

\begin{tabular}{lccll}
\hline \hline & & & \\
Method & Statistic & Prob. ${ }^{* *}$ & $\begin{array}{l}\text { Cross- } \\
\text { sections }\end{array}$ & Obs \\
\hline Null: Unit root (assumes common unit root process) & & \\
\hline \multicolumn{7}{l}{ Levin, Lin \& Chut* } \\
\multicolumn{7}{l}{$-1,46729$} & 0,0711 & 6 & 120 \\
Null: Unit root (assumes individual unit root process) & & \\
\hline Im, Pesaran and Shin W-stat & $-1,67587$ & 0,0469 & 6 & 120 \\
ADF - Fisher Chi-square & 19,7501 & 0,0720 & 6 & 120 \\
PP - Fisher Chi-square & 19,6771 & 0,0734 & 6 & 126 \\
\hline \hline
\end{tabular}

** Probabilities for Fisher tests are computed using an asymptotic Chisquare distribution. All other tests assume asymptotic normality.

Panel unit root test: Summary

Series: OPEN

Date: 06/07/19 Time: 09:21

Sample: 1995-2017

Exogenous variables: Individual effects

User-specified lags: 1

Newey-West automatic bandwidth selection and Bartlett kernel

\begin{tabular}{|c|c|c|c|c|}
\hline Method & Statistic & Prob.** & $\begin{array}{l}\text { Cross- } \\
\text { sections }\end{array}$ & Obs \\
\hline \multicolumn{5}{|c|}{ Null: Unit root (assumes common unit root process) } \\
\hline Levin, Lin \& Chut* & $-2,71180$ & 0,0033 & 6 & 125 \\
\hline \multicolumn{5}{|c|}{ Null: Unit root (assumes individual unit root process) } \\
\hline Im, Pesaran and Shin W-stat & $-2,70361$ & 0,0034 & 6 & 125 \\
\hline ADF - Fisher Chi-square & 30,4587 & 0,0024 & 6 & 125 \\
\hline PP - Fisher Chi-square & 23,6038 & 0,0230 & 6 & 131 \\
\hline
\end{tabular}

** Probabilities for Fisher tests are computed using an asymptotic Chisquare distribution. All other tests assume asymptotic normality. 
174 Vijay Shenai, Artem Shcherbyna, Sergei voronin, Dmitriy olkhousky

The Determinants of FDI in six former FSU countries: a study of data 1995-2017

Panel unit root test: Summary

Series: D (LRGDP)

Date: 06/07/19 Time: 11:18

Sample: 1995-2017

Exogenous variables: Individual effects

User-specified lags: 1

Newey-West automatic bandwidth selection and Bartlett kernel

\begin{tabular}{|c|c|c|c|c|}
\hline Method & Statistic & Prob. ${ }^{* *}$ & $\begin{array}{l}\text { Cross- } \\
\text { sections }\end{array}$ & Obs \\
\hline \multicolumn{5}{|c|}{ Null: Unit root (assumes common unit root process) } \\
\hline Levin, Lin \& Chut $^{*}$ & $-3,19238$ & 0,0007 & 6 & 119 \\
\hline \multicolumn{5}{|c|}{ Null: Unit root (assumes individual unit root process) } \\
\hline Im, Pesaran and Shin W-stat & $-2,23175$ & 0,0128 & 6 & 119 \\
\hline ADF - Fisher Chi-square & 22,8593 & 0,0289 & 6 & 119 \\
\hline PP - Fisher Chi-square & 37,1317 & 0,0002 & 6 & 125 \\
\hline
\end{tabular}

** Probabilities for Fisher tests are computed using an asymptotic Chisquare distribution. All other tests assume asymptotic normality. 
Appendix 3

ARDL model

Dependent Variable: D (FDIGDP)

Method: ARDL

Date: 07/23/19 Time: 13:18

Sample: 1996-2017

Included observations: 132

Dependent lags: 1 (Fixed)

Dynamic regressors (1 lag, fixed): INF OPEN LEXRTOS LINFRAFM LRGDP

LGNIPC

Fixed regressors: $\mathrm{C}$

\begin{tabular}{|c|c|c|c|c|}
\hline Variable & Coefficient & Std. Error & t-Statistic & Prob.* \\
\hline & \multicolumn{4}{|c|}{ Long Run Equation } \\
\hline INF & 0,079224 & 0,018872 & 4,198052 & 0.0001 \\
\hline OPEN & $-0,027903$ & 0,027254 & $-1,023807$ & 0.3089 \\
\hline LEXRTO\$ & $-0,350510$ & 0,344763 & $-1,016669$ & 0.3122 \\
\hline LINFRAFM & 2,772973 & 0,662335 & 4,186663 & 0.0001 \\
\hline LRGDP & $-9,160902$ & 4,919292 & $-1,862240$ & 0.0661 \\
\hline \multirow[t]{2}{*}{ LGNIPC } & 0,781589 & 5,158038 & 0,151528 & 0.8799 \\
\hline & \multicolumn{4}{|c|}{ Short Run Equation } \\
\hline COINTEQ01 & $-0,739679$ & 0,072572 & $-10,19235$ & 0.0000 \\
\hline $\mathrm{D}(\mathrm{INF})$ & 0,022700 & 0,004301 & 5,277462 & 0.0000 \\
\hline D(OPEN) & $-0,029800$ & 0,028642 & $-1,040424$ & 0.3011 \\
\hline D(LEXRTO\$) & $-3,612097$ & 4,209936 & $-0,857993$ & 0.3933 \\
\hline D(LINFRAFM) & 6,246148 & 3,245148 & 1,924765 & 0.0576 \\
\hline D(LRGDP) & 49,72394 & 14,95211 & 3,325546 & 0.0013 \\
\hline D(LGNIPC) & $-51,55471$ & 19,38409 & $-2,659640$ & 0.0094 \\
\hline $\mathrm{C}$ & 159,0206 & 16,29852 & 9,756749 & 0.0000 \\
\hline \multicolumn{5}{|c|}{ Mean dependent } \\
\hline & 0,034543 & \multirow{2}{*}{\multicolumn{2}{|c|}{ S,D, dependent var }} & 2,606450 \\
\hline S. E. of regression & 1,877813 & & & 3,854936 \\
\hline Sum squared resid & 296,1993 & \multicolumn{2}{|c|}{$\begin{array}{l}\text { Akaike info criterion } \\
\text { Schwarz criterion }\end{array}$} & 5,000383 \\
\hline Log likelihood & $-211,9906$ & \multicolumn{2}{|c|}{ Hannan-Quinn criter, } & 4,320417 \\
\hline
\end{tabular}

*Note: $p$-values and any subsequent tests do not account for model selection. 
Armenia

\begin{tabular}{|l|l|l|l|l|}
\hline Variable & Coefficient & Std. Error & t-Statistic & Prob. \\
\hline COINTEQ01 & -0.826476 & 0.021267 & -38.86181 & 0.0000 \\
\hline $\mathrm{D}($ INF $)$ & 0.032501 & 0.000181 & 179.2576 & 0.0000 \\
\hline $\mathrm{D}($ OPEN) & -0.092645 & 0.005138 & -18.03051 & 0.0004 \\
\hline $\mathrm{D}($ LEXRTO\$) & -15.71974 & 37.78632 & -0.416017 & 0.7054 \\
\hline $\mathrm{D}($ LINFRAFM) & 1.254757 & 2.815636 & 0.445639 & 0.6861 \\
\hline $\mathrm{D}($ LRGDP) & 45.12392 & 652.5873 & 0.069146 & 0.9492 \\
\hline $\mathrm{D}($ LGNIPC) & -54.39504 & 468.3428 & -0.116144 & 0.9149 \\
\hline $\mathrm{C}$ & 165.9550 & 4587.979 & $0 . .036172$ & 0.9734 \\
\hline
\end{tabular}

Belarus

\begin{tabular}{|l|l|l|l|l|}
\hline Variable & Coefficient & Std. Error & t-Statistic & Prob. \\
\hline COINTEQ01 & -0.549974 & 0.011420 & -48.16072 & 0.0000 \\
\hline $\mathrm{D}($ INF $)$ & 0.007223 & $3.84 \mathrm{E}-06$ & 1879.410 & 0.0000 \\
\hline $\mathrm{D}($ OPEN $)$ & 0.074583 & 0.000287 & 260.2358 & 0.0000 \\
\hline $\mathrm{D}($ LEXRTO $)$ & -8.114369 & 2.680288 & -3.027424 & 0.0564 \\
\hline $\mathrm{D}($ LINFRAFM $)$ & 0.440757 & 14.27620 & 0.030874 & 0.9773 \\
\hline $\mathrm{D}($ LRGDP) & 123.2848 & 1621.433 & 0.076034 & 0.9442 \\
\hline $\mathrm{D}($ LGNIPC) & -142.7391 & 1406.950 & -0.101453 & 0.9256 \\
\hline $\mathrm{C}$ & 117.6110 & 2126.012 & 0.055320 & 0.9594 \\
\hline
\end{tabular}

Kazakhstan

\begin{tabular}{|l|l|l|l|l|}
\hline Variable & Coefficient & Std. Error & t-Statistic & Prob. \\
\hline COINTEQ01 & -0.914976 & 0.038113 & -24.00699 & 0.0002 \\
\hline D(INF) & 0.034673 & 0.000679 & 51.09229 & 0.0000 \\
\hline D(OPEN) & -0.092900 & 0.008672 & -10.71258 & 0.0017 \\
\hline D(LEXRTO\$) & 14.52547 & 35.82769 & 0.405426 & 0.7123 \\
\hline D(LINFRAFM) & 12.66676 & 44.20837 & 0.286524 & 0.7931 \\
\hline D(LRGDP) & 29.79065 & 1258.965 & 0.023663 & 0.9826 \\
\hline D(LGNIPC) & -9.309195 & 649.0404 & -0.014343 & 0.9895 \\
\hline C & 202.6005 & 7083.616 & 0.028601 & 0.9790 \\
\hline
\end{tabular}

Moldova

\begin{tabular}{|l|l|l|l|l|}
\hline Variable & Coefficient & Std. Error & t-Statistic & Prob. \\
\hline COINTEQ01 & -0.648552 & 0.016065 & -40.37127 & 0.0000 \\
\hline $\mathrm{D}($ INF $)$ & 0.025580 & 0.001837 & 13.92190 & 0.0008 \\
\hline $\mathrm{D}($ OPEN $)$ & 0.000169 & 0.003187 & 0.053064 & 0.9610 \\
\hline $\mathrm{D}($ LEXRTO $)$ & -0.776404 & 9.297791 & -0.083504 & 0.9387 \\
\hline $\mathrm{D}($ LINFRAFM) & 18.92377 & 20.29179 & 0.932583 & 0.4198 \\
\hline $\mathrm{D}($ LRGDP) & 40.18835 & 268.1015 & 0.149900 & 0.8904 \\
\hline $\mathrm{D}($ LGNIPC) & -44.07856 & 201.4220 & -0.218837 & 0.8408 \\
\hline $\mathrm{C}$ & 125.7762 & 2920.802 & 0.043062 & 0.9684 \\
\hline
\end{tabular}




\section{Russia}

\begin{tabular}{|l|l|l|l|l|}
\hline Variable & Coefficient & Std. Error & t-Statistic & Prob. \\
\hline COINTEQ01 & -0.555050 & 0.019943 & -27.83207 & 0.0001 \\
\hline D(INF) & 0.014528 & $3.57 E-05$ & 406.5583 & 0.0000 \\
\hline D(OPEN) & -0.083249 & 0.004904 & -16.97503 & 0.0004 \\
\hline D(LEXRTO\$) & -2.768105 & 2.320724 & -1.192777 & 0.3187 \\
\hline D(LINFRAFM) & -1.137960 & 1.461555 & -0.778596 & 0.4930 \\
\hline D(LRGDP) & 28.17118 & 667.5065 & 0.042204 & 0.9690 \\
\hline D(LGNIPC) & -21.41328 & 491.6968 & -0.043550 & 0.9680 \\
\hline C & 132.9417 & 3468.946 & 0.038323 & 0.9718 \\
\hline
\end{tabular}

Ukraine

\begin{tabular}{|l|l|l|l|l|}
\hline Variable & Coefficient & Std. Error & t-Statistic & Prob. \\
\hline COINTEQ01 & -0.943046 & 0.023453 & -40.21026 & 0.0000 \\
\hline D(INF) & 0.021697 & $4.69 \mathrm{E}-05$ & 462.8110 & 0.0000 \\
\hline D(OPEN) & 0.015244 & 0.001936 & 7.875118 & 0.0043 \\
\hline D(LEXRTO $)$ & -8.819436 & 10.77807 & -0.818276 & 0.4731 \\
\hline D(LINFRAFM) & 5.328803 & 5.106674 & 1.043498 & 0.3734 \\
\hline D(LRGDP) & 31.78467 & 391.2887 & 0.081231 & 0.9404 \\
\hline D(LGNIPC) & -37.39310 & 299.8357 & -0.124712 & 0.9086 \\
\hline C & 209.2392 & 7339.965 & 0.028507 & 0.9790 \\
\hline
\end{tabular}

\section{References}

1. Abbott A., Cushman D., De Vita G. (2012). Exchange rate regimes and foreign direct investment flows to developing countries. Review of International Economics, 20 (1), pp. 95-107.

2. Akram M. (2011). The Impact of Infrastructure on Foreign Direct Investment: The Case of Pakistan. International Journal of Business and Management, 6(5).

3. Andinuur J. (2013). Inflation, Foreign Direct Investment and Economic Growth in Ghana. University of Ghana. Retrieved from: http://ugspace.ug.edu.gh:8080/handle/123456789/5334.

4. Ang J. (2008). Determinants of foreign direct investment in Malaysia. Journal of Policy Modeling, Elsevier, 30(1), pp. 185-189.

5. Anyadike N. (2012). Poor Infrastructure: The Hindrance to Foreign Investment and Economic Development in Nigeria. Interdisciplinary Journal of Contemporary Research in Business, 4(4).

6. Azam M. (2010). Determinants of Foreign Direct Investment in India, Indonesia and Pakistan: A Quantitative Approach. Retrieved from: https://www.researchgate.net/publication/273757902. 
7. Babatunde A. (2011). Trade Openness, Infrastructure, FDI and Growth in Sub-Saharan African Countries. Journal of Management Policy and Practice, 12(7).

8. Bakar N., Mat S., Harun M. (2012). The Impact of Infrastructure on Foreign Direct Investment: The Case of Malaysia. Procedia - Social and Behavioral Sciences, 65, pp. 205-211.

9. Becker J., Fuest C., Ridel N. (2012). Corporate tax effects on the quality and quantity of FDI. European Economic Review, 56 (8), pp. 1495-1511. Retrieved from: http://dx.doi.org/10.1016/j.euroecorev.2012.07.001.

10. Behname M. (2012). Foreign Direct Investment and Economic Growth: Evidence from Southern, Asia. Atlantic Review of Economics, 2.

11. Callen T. (2008). Back to Basics. What Is Gross Domestic Product? Finance \& Development. Retrieved from: http://www.imf.org/external/pubs/ft/fandd/ 2008/12/pdf/basics.pdf.

12. Chakrabarti A. (2001). The Determinants of Foreign Direct Investments: Sensitivity Analyses of Cross-Country Regressions. Kyklos, 54 (1), pp. 89114. Retrieved from: http://doi.wiley.com/10.1111/1467-6435.00142.

13. Chakrabarti R., Subramanian K., Meka S., Sudershan K. (2012), Infrastructure and FDI: Evidence from district-level data in India, Retrieved from: https://www.isb.edu/faculty/KrishnamurthySubramanian/Images/FDI_infra_20 Mar2012_ReStud.pdf

14. Chong L., Tan H. (2008). Exchange rate risk and macroeconomic fundamentals: evidence from four neighbouring Southeast Asian economies. International Research Journal of Finance and Economics, 16, pp. 88-95.

15. Culem C. G. (1988). The locational determinants of direct investments among industrialized countries. European Economic Review, Elsevier, 32(4), pp. 885-904.

16. Cushman D. (1985). Real Exchange Rate Risk, Expectations, and the Level of Direct Investment. The Review of Economics and Statistics, 67(2), pp. 297-308.

17. Dunning J. (1977). Trade, Location of Economic Activity and the MNE: A Search for an Eclectic Approach. The International Allocation of Economic Activity. Palgrave Macmillan, London

18. Dunning J. (1993). Multinational Enterprises and the Global Economy. Addison Wesley Publishing Co., Harlow, Essex.

19. Edwards S. (1990). Capital Flows, Foreign Direct Investment, and DebtEquity Swaps in Developing Countries. NBER Working Paper No. 3497, National Bureau of Economic Research.

20. Essia U., Onyema J. (2012). Determinants of Foreign Direct Investment in Nigeria. Journal of Money, Investment and Banking, (25). 
21. Faroh A., Shen H. (2015). Impact of Interest Rates on Foreign Direct Investment : Case Study Sierra Leone Economy. International Journal of Business Management and Economic Research, 6 (1), pp. 124-132.

22. Fedderke J., Romm A. (2006). Growth impact and determinants of foreign direct investment into South Africa, 1956-2003. Economic Modelling, 23(5), pp. 738-760.

23. Feldstein M. (2000). Aspects of Global Economic International Integration, outlook for the future. NBER working paper No. 7899, National Bureau of Economic Research.

24. Foellmi R., Grossmann S., Kohler A. (2018). A dynamic North-South model of demand-induced product cycles. Journal of International Economics, 110, pp. 63-86.

25. Fung K., Garcia-Herrero A., Izaka H., Siu A. (2005). Hard or Soft? Institutional Reforms and Infrastructure spending as Determinants of foreign direct investment in China. The Japanese Economic Review, 56(4), pp. 408-416.

26. Hymer S. (1972). Internalization of Capital. Journal of Economic Issues, pp. 91-111.

27. Hymer S. (1976). The International Operations of National Firms: A Study of Direct Foreign Investment. Cambridge. MIT Press.

28. IMF (1993). Foreign Direct Investment Trends and Statistics: A Summary IMF. Retrieved from: https://www.imf.org/External/np/sta/fdi/eng/2003/ 102803s1.pdf

29. IMF Data on Indicators. Retrieved from: https://www.imf.org/en/Data

30. Jaspersen F., Aylward A., Knox A. (2000). Risk and Private Investment: Africa Compared with Other Developing Areas. Investment and Risk in Africa. Studies on the African economies. Palgrave Macmillan, London

31. Jones C., Temouri Y. (2016). The determinants of tax haven FDI. Journal of World Business, 51 (2), pp. 237-250. Retrieved from: http://dx.doi.org/ 10.1016/j.jwb.2015.09.001

32. Jordaan J. (2004). Foreign Direct Investment and Neighbouring Influences. Unpublished doctoral thesis, University of Pretoria.

33. Kamath G. (2008). Impact of foreign direct investment in India. The ICFAI University Journal of International Business, 3(4), pp. 16-38.

34. Karkinsky T., Riedel N. (2012). Corporate taxation and the choice of patent location within multinational firms. Journal of International Economics, 88 (1), Retrieved from: http://dx.doi.org/10.1016/j.jinteco.2012.04.002.

35. Khan S., Mitra P. (2014). A Causal Linkage between FDI Inflows with Select Macroeconomic Variables in India - An Econometric Analysis. IOSR Journal of Economics and Finance, 5(5), pp. 124-133. 
36. Kosekahyaoglu L. (2006). A comparative analysis of FDI in Turkey and the CEECS: Is there any link between FDI and Trade? Journal of Business Economics and Management, 7(4), pp. 183-200.

37. Kravis I., Lipsey R. (1982). The location of overseas production and production for export by U.S. multinational firms. Journal of International Economics, 12 (3-4), pp. 201-223.

38. Kurecic P., Luburic G. (2015). The influence of the size of the economy and European integration on foreign direct investments in the Central, Southeastern and Eastern European states 1994-2013. Conference Paper.

39. Lily J., Kogid M., Mulok D., Thien Sang L., Asid R. (2014). Exchange Rate Movement and Foreign Direct Investment in Asean Economies. Economics Research International.

40. Loungani P., Razin A. (2001). How beneficial is foreign direct investment for developing countries? Finance and Development, 38 (2).

41. Valli M., Masih M. (2014). Is there any causality between inflation and FDI in an 'inflation targeting' regime? Evidence from South Africa. Retrieved from: https://www.semanticscholar.org/paper/Is-there-any-causality-between-inflationand-FDI-in-Valli-Masih/16e7a7b90ffcf47f4f2ca6ba587dc8e89ab4b975

42. Obiamaka P., Onwumere J., Okpara G. (2011). Foreign direct investment and economic growth in Nigeria: A granger causality analysis, International Journal of Current Research, 3 (11), pp. 225-232.

43. OECD. (1990). OECD Benchmark Definition of Foreign Direct Investment. Retrieved from: https://www.oecd.org/daf/inv/investment-policy/2090148.pdf

44. OECD. (2017). Local Content Policies in Minerals-Exporting Countries: The Case of Australia. Trade Policy Note. Retrieved from: www.oecd.org/trade.

45. Omankhanlen, A. (2011). The Effect of Exchange Rate and Inflation on Foreign Direct Investment and its relationship with Economic Growth in Nigeria. Economics and Applied Information, 1, pp. 5-16.

46. Omezzine A., Hakro N. (2011). FDI Flows and Governance in MENA Countries. Middle Eastern Finance and Economics, 12, pp. 143-156.

47. Pärletun J., Thede S. (2008). The Determinants of Foreign Direct Investment: A Regional Analysis with Focus on Belarus. Lund University, pp. 10-16.

48. Seetanah B. (2009). A Sector-Wise Panel Data Study on the Link between Transport Infrastructure and FDI in Mauritius. 9th Global Conference on Business \& Economics.

49. Schneider F., Frey B. (1985). Economic and political determinants of foreign direct investment. World Development, 13 (2), pp. 161-17

50. Sekkat K., Veganzones-Varoudakis M. (2007). Openness, investment climate, and FDI in developing countries. Review of Development Economics, 11 (4), pp. 607-620. 
51. Schmitz A., Bieri J. (1972). EEC Tariffs and U.S. Direct Investment. European Economic Review, 3 (3), pp. 259-270.

52. Siddiqui H., Aumeboonsuke V. (2014). Role of Interest Rate in Attracting the FDI : Study on Asean 5 Economy. International Journal of Technical Research and Applications, 2 (1), pp. 59-70.

53. Simmons R. (2003). An empirical study of the impact of corporate taxation on the global allocation of foreign direct investment: A broad tax attractiveness index approach. Journal of International Accounting, Auditing and Taxation, 12 (2), pp. 105-120.

54. Suliman A., Elmawazini K., Shariff, M. (2015). Exchange Rates and Foreign Direct Investment: Evidence for Sub-Saharan Africa. The Journal of Developing Areas, 49 (2), pp. 203-226.

55. Tsai P. (1994) Determinants of Foreign Direct Investment and Its Impact on Economic Growth. Journal of Economic Development, 19.

56. UNCTAD. (2018). World investment Report. Retrieved from: https://unctad.org/ en/PublicationsLibrary/wir2018_en.pdf

57. Vernon R. (1966). International Investment and International Trade in the Product Cycle. The Quarterly Journal of Economics, 80 (2), pp. 190. Retrieved from: https://academic.oup.com/qje/article-lookup/doi/10.2307/1880689.

58. Walsh J. Yu J. (2010). Determinants of Foreign Direct Investment: A Sectoral and Institutional Approach. IMF Working Papers, pp. 1-27, Retrieved from: https://ssrn.com/abstract $=1662260$

59. Wafure O., Nurudeen A. (2010). Determinants of Foreign Direct Investment in Nigeria: An Empirical Analysis. Retrieved from: https://www.researchgate.net/ publication/265627570

60. Wheeler D., Mody A. (1992). International investment location decisions: The case of U.S. firms. Journal of International Economics, 33 (1-2), pp. 57-76.

61. World Bank Data on Indicators. Retrieved from: https://data.worldbank.org/ indicator

62. World Investment Report. (2018). Retrieved from: https://unctad.org/en/ pages/PublicationWebflyer. aspx?publicationid $=2130$

63. Xaypanya P., Rangkakulnuwat P., Paweenawat S. (2015). The determinants of foreign direct investment in ASEAN: The first differencing panel data analysis. International Journal of Social Economics 42 (3), pp. 239-250.

64. Xing Y., Wan G. (2006). Exchange Rates and Competition for FDI in Asia. The World Economy, 29 (4). 